\title{
Hodowla oraz właściwości prozdrowotne ziemniaków o fioletowej barwie miąższu
}

\author{
Breeding and health-promoting properties of potatoes with purple \\ fleshed color
}

\section{Aleksandra Bech $\bowtie$}

Hodowla Ziemniaka Zamarte Sp. z o.o. - Grupa IHAR, ul. Parkowa 1, Zamarte, 89-430 Kamień Krajeński, $\triangle$ e-mail: a.bech@zamarte.com

\begin{abstract}
Na podstawie prac hodowlanych prowadzonych w firmie Hodowla Ziemniaka Zamarte Sp. z o.o. - Grupa IHAR, scharakteryzowano strukturę, etapy oraz specyfikę hodowli ziemniaków o fioletowej barwie miąższu. Opisano działanie prozdrowotne antocyjanów zawartych w bulwach o tej barwie miąższu. Przedstawiono dotychczasowe zaawansowanie prac hodowlanych. Rejestracja rodu ziemniaka o fioletowej barwie miąższu, o planowanej nazwie 'Provita', przewidywana jest na rok 2021 i, być może, zostanie ona pierwszą polską odmianą o fioletowej barwie miąższu.
\end{abstract}

Słowa kluczowe: Hodowla Ziemniaka Zamarte, Provita, ziemniaki o fioletowej barwie miąższu, zawartość antocyjanów

The structure, stages and breeding specificity of purple fleshed potatoes at Zamarte Potato Breeding Ltd. - IHAR Group are characterized in the article. The health-promoting effects of anthocyanins occurred in the purple tubers have also been described. The progress of breeding works has been presented. As a result of breeding efforts registration of the potato purple clones, with the planned name 'Provita', is scheduled for 2021. Presumably, it will be the first Polish variety of potato with purple flesh.

Key words: Zamarte Potato Breeding Ltd. - IHAR Group, Provita, purple fleshed potatoes, anthocyanin content

\section{Wstęp}

W Polsce, wśród roślin uprawnych ziemniak zajmuje jedno z czołowych miejsc, stąd prace badawcze nad ulepszeniem istniejących odmian oraz poszukiwanie nowych prowadzi się od wielu lat i w różnych częściach kraju. Prace hodowlane w Hodowli Ziemniaka Zamarte prowadzone są nieprzerwanie od 1945 roku. Obecnie hodowla jest podzielona na trzy główne kierunki:

- Pierwszy dotyczy ziemniaków na cele jadalne. W tej grupie możemy wyróżnić ziemniaki na bardzo wczesny zbiór, ziemniaki o białym i żółtym miąższu, do pakowania, o podwyższonej tolerancji na suszę i ekstremalnie wysokie temperatury oraz ziemniaki do produkcji ekologicznej, które wyróżniają się podwyższoną odpornością na Phytophthora infestans. Do tego kierunku zalicza się również ziemniaki o fioletowej barwie miąższu, który jak dotąd są spożywane przez niewielką grupę konsumentów, jako purée lub dodatek do sałatek.

- Drugi obejmuje ziemniaki przeznaczone do przemysłu. Tu można wyodrębnić ziemniaka frytkowego, chipsowego oraz ziemniaki do uzyskiwania produktów uszlachetnionych.

- Trzeci nastawiony jest na hodowlę ziemniaka skrobiowego, charakteryzującego się wysoką zawartością skrobi.

W strukturze hodowli w HZ Zamarte, $56 \%$ uzyskanych form w pierwszym etapie hodowli stanowią ziemniaki na cele jadalne, z wyłączeniem form o podwyższonej odporności na zarazę ziemniaka (5\%) oraz formy o fioletowej barwie miąższu, które stanowią tylko $1 \% \mathrm{w}$ strukturze całej hodowli. Rozkład form pozostałych kierunków, tj. ziemniaka frytkowego, chipsowego oraz skrobiowego jest proporcjonalny i wynosi odpowiednio $12 \%$, $10 \%, 16 \%$.

Celem działania hodowcy określonej odmiany rośliny jadalnej jest, między innymi, uzyskanie produktu o pożądanych walorach prozdrowotnych i odżywczych. Taką rośliną, według doniesień naukowców, jest ziemniak o fioletowej barwie miąższu. Stąd przed około 15 laty w HZ Zamarte w pracy hodowlanej zwrócono uwagę na uzyskanie ziemniaka o tej barwie miąższu. 
Warto zaznaczyć, że hodowla omawianego kierunku nie należy do najłatwiejszych $\mathrm{z}$ tego chociażby powodu, że ilość uzyskiwanych form na etapie siewek, w porównaniu do innych kierunków jest niewielka, bo wynosi zaledwie około 700 siewek rocznie.

Drugą istotną kwestią jest niewielkie zaintereł sowanie przemysłu, handlu oraz konsumentów fioletowymi ziemniakami. Dopiero od niedawna zaobserwowano wzrost zainteresowania ziemniakami o kolorowym miąższu. Prawdopodobnie jest to spowodowane większą świadomością klientów poszukujących produktów alternatywnych, zawierających, oprócz składników występujących w tradycyjnej formie, także takich, które mają dodatkowe substancje bioaktywne (Kudełka, Łobaza 2007). Celem pracy jest przedstawienie hodowli ziemniaka o fioletowej barwie miąższu oraz ukazanie i popularyzacja ich właściwości prozdrowotnych.

\section{Związki odpowiedzialne za fioletową barwę miąższu bulw ziemniaka}

W kręgu zainteresowania zarówno biochemików jak i hodowców są związki odpowiadające za fioletowy kolor miąższu bulw ziemniaka oraz ich właściwości prozdrowotne. Są nimi antocyjany, związki będące pochodnymi petunidyny i malwidyny a należące do polifenolowych związków organicznych - flawonoidów (Lachamn, Hamouz 2005). Według Nemś i in. (2015) odmiany o kolorowym miąższu odznaczają się 6-7 - krotnie większą aktywnością przeciwutleniającą niż odmiany jasne, które charakteryzują się potencjałem antyoksydacyjnym na poziomie $6 \mu \mathrm{mol}$ Trolox/g suchej masy. Natomiast Mulinacci i in. (2008) podają, że zawartość związków polifenolowych w ziemniakach o białym miąższu wynosiła $12,1 \mathrm{mg} \cdot 100$ świeżej masy, a o czerwonym i fioletowym miąższu prawie dziesięciokrotnie więcej-średnio 1.1,^ mg·100 . Zawartość flawonoidów w bulwach różnicowana jest głównie przez genotyp. Odmiany o intensywnie wybarwionym miąższu wykazują większą aktywność przeciwutleniającą (Wierzbicka i in. 2015). Antocyjany korzystnie wpływają na organizm człowieka, ponieważ prowadzą do wygaszania wolnych rodników tlenowych $\mathrm{m}$. in. rodnika hydroksylowego, tlenu singletowego, anionorodnika ponadtlenkowego i tym samym chronią DNA przed uszkodzeniami (Renis i in. 2007). O tym, że ich działanie jest znaczące dla zdrowia człowieka, świadczą też kolejne spostrzeżenia badaczy. Blokując różne etapy cyklu komórkowego, poprzez wpływ na białka regulatorowe, hamują proliferację komórkową w komórkach nowotworowych, aktywują też proces apoptozy, czyli zaprogramowanej śmierci komórki (Zhang i in. 2005). Ponadto uruchamiają wewnątrz- i zewnątrzkomórkowe szlae ki przekazu sygnału, m. in. regulują ekspresję różnych genów, regulują uwolnienie enzymów pro$i$ antyapoptycznych białek (Feng i in. 2007). Powyższe mechanizmy ukazują działanie protekcyjne w chorobach nowotworowych. W trakcie badań dowiedziono również, że produkty bogate w antocyjany mogą korzystnie wpływać na profil lipidowy, powodując jego obniżenie oraz potrafią zwiększać wrażliwość na insulinę. Prócz tego obserwowano zmniejszenie zmian miażdżycowych w naczyniach krwionośnych (Zawistowski $\mathrm{i}$ in. 2009). Co więcej, przeciwdziałają one kruchości naczyń krwionośnych, przede wszystkim naczyń włosowatych oraz stymulują produkcję rodopsyny, substancji niezbędnej w procesie widzenia zmierzchowego (Matsumoto i in. 2003). Warto podkreślić, że do tej pory nie wykryto żadnych negatywnych skutków oddziaływania antocyjanów na organizm człowieka i tym samym należy zalecać je w diecie wymagającej zwiększenia podaży produktów bogatych $w$ te związki (Piątkowska $i$ in. 2011). Można zatem przyjąć, że zastąpienie ziemniaków o białej lub żółtej barwie miąższu ziemniakami o fioletowym miąższu zwiększy ilość antocyjanów w diecie. Ponadto wszystkie ziemniaki, nie tylko o fioletowej barwie miąższu, ale również te o tradycyjnej barwie miąższu z punktu widzenia żywieniowego zawierają wiele cennych substancji. W swoim składzie posiadają, bowiem łatwostrawne węglowodany, które występują w około $80 \%$ suchej masy, ale także białko (6-10\% suchej masy), bogate w aminokwasy endogenne, porównywalne $\mathrm{z}$ wartością odżywczą białka jaja kurzego (Eppendorfer 1994).

\section{Selekcja materiału hodowlanego}

Hodowla ziemniaków o fioletowej barwie miąższu zaczyna się od odpowiedniego dobrania komponentów rodzicielskich. Ważne jest, by jedna $\mathrm{z}$ form charakteryzowała się intensywnie oraz równomiernie wybarwionym miąższem, druga zaś wnosiła cechy jakościowe i ilościowe pozytywne z punktu widzenia hodowcy. Do tych cech zaliczyć można m. in. krótki okres wegetacji, płytkie oczka, regularny kształt bulw, gładką skórkę, wysoki plon. Na wczesnym etapie hodowli odrzuca się rody, u których nie wystąpił pigment niebieski. Wybarwienie miąższu występuje tylko w przypadku wystąpienia genu głównego $P$, w obecności epistatycznie oddziaływającego genu $I$. Natomiast nasilenie barwy zależne jest od poligenicznych 
modyfikatorów (Zimnoch-Guzowska 2006). $\mathrm{W}$ późniejszych etapach hodowli odrzucane są rody, u których wystąpił tzw. „marmurek”, czyli miąższ przechodzi z koloru fioletowego w biały lub żółty, tworząc nieregularne jasne plamy w strukturze miąższu. Niestety, nie tylko nierównomierne wybarwienie miąższu może zdecydować o zdyskwalifikowaniu rodu $\mathrm{z}$ dalszej hodowli. Cechy, które przyczyniają się do eliminacji rodów to bardzo długi okres wegetacji - odmiany późne nie mają szans zaistnieć na rynku. Niepożądane są również bardzo głębokie oczka, które utrudniają konfekcjonowanie oraz obieranie bulw. Odrzucane są również rody, które nie odznaczają się dobrym smakiem oraz nieatrakcyjnie wyglądają po ugotowaniu (utrata intensywności koloru).

W okresie prac hodowlanych występują różne czynniki biotyczne i abiotyczne, które pośrednio lub bezpośrednio wpływają na cechy ilościowe i jakościowe tworzonych rodów. W przypadku hodowli ziemniaków o fioletowej barwie miąższu duże znaczenie ma nasłonecznienie w trakcie sezonu wegetacyjnego oraz ataki szkodników (stonka, mszyca). Wymienione czynniki mają bezpośredni wpływ na rozkład barwnika w roślinie oraz akumulację antocyjanów w bulwach. Dzieje się tak, ponieważ w trakcie wzrostu rośliny, antocyjany są najpierw syntezowane w częściach nadziemnych rośliny a dopiero potem w częściach podziemnych. Lewis $i$ in. (1998) sugerują, że w liściach pod wpływem światła następuje wytwarzanie nieznanego związku, który następnie migruje do innych organów rośliny, takich jak bulwy, wysyłając sygnał do syntezy barwników antocyjanowych. W sezonie wegetacyjnym o przewadze dni słonecznych można zaobserwować mniej intensywne wybarwienie bulw pigmentem niż w sezonie $\mathrm{z}$ przewagą dni pochmurnych. Hodowca w pracach selekcyjnych podczas zbioru musi mieć wgląd w dokumentację warunków panujących w całym sezonie wegetacyjnym. Kolejnym czynnikiem mogącym wpływać na nagromadzenie antocyjanów w bulwach są szkodniki. Zraniona roślina, transportując antocyjany ze zdrowych części roślin w okolice zranionej tkanki, gromadzi antocyjany w zdrowych komórkach w bliskiej odległości uszkodzonych komórek. Funkcja antocyjanów w roślinie nie została jeszcze do końca poznana. Przypuszcza się, że chronią one zdrowe komórki roślin przed stresem oksydacyjnym (Dioxon 1995).

Po 12 latach prac hodowlanych w HZ Zamarte wyhodowano ród, który został zgłoszony do badań rejestrowych w Centralnym Ośrodku Badań Odmian Roślin Uprawnych. Prawdopodobnie zostanie on zarejestrowany w roku 2021, oczywiście, jeśli przejdzie pomyślnie okres dwuletnich badań rejestrowych. Hodowca zaproponował nazwę 'Provita'. Być może będzie to pierwsza zarejestrowana polska odmiana ziemniaka o fioletowej barwie miąższu.

\section{Literatura}

Dioxon, R. A., Paiva, N. L. (1995), Stress-induced phenylpropanoid metabolizm. Plant Cell, 7, 1085-1097

Eppendorfer, W. H., Eggun, B.O.E., (1994). Effect of sulphur, nitrogen, phosphorus, potassium and water stress on dietary fibre fractions, starch, amino acids and on the biological value of potato protein. Plant Foods Hum. Nutr., 45, 299-313

Feng, R., Ni, M. H., Wang, S.Y., Tourkova, I. L., Shurin, M. R., Harada, H., Yin, X. M., (2007), Cyanidin-3-rutinoside, a natural polyphenol antioxidant, selectively kills leukemic cells by induction of oxidantive stress., J. Biol. Chem., 282, 13468-13476

Kudełka, W., Łobaza, D., (2007), Charakterystyka żywności funkcjonalnej. Zeszyty Naukowe Akademii Ekonomicznej w Krakowie, 743, 91-120

Lachamn, J., Hamouz, K., (2005), Red and purple coloured potatoes as a significant antioxidant sourcee in human nutrition - a review. J. Plant Soil Environ., 51, 477-482

Lewis, C. E., Walter, J. R. L. Lancaster, J. E., Conner, A. J., (1988), Light regulation of anthocyanin, flavonoid and phenolic acid biosynthesis in potato minitubers in vitro. Austr. J. Plant Physiol. 25, 915-922

Matsumoto, H., Nakamura, Y., Tachibanaki, S., Kawamura, S., Hirayama, M., (2003). Stimulatory effect of cyanidin 3 -glycosides on the regeneration of rhodopsin. J. Agric. Food Chem., 51, 3560-3563

Mulinacci, N., Ieri, F., Giaccherini, C., Innocenti, M., Andrenelli, L., Canova, G., Saracchi, M., Casiraghi, M. C., (2008). Effect of cooking on the anthocyanins, phenolic AIDS, glycoalkaloids, and resistant starch content in two pigmented cultivars of Solanum tuberosum L. J. Agric. Food Chem. 56, 11830-11837

Nemś, A., Miedzianka, J., Pęksa, A., Kita, A., (2015), Zawartość związków prozdrowotnych w ziemniakach odmian o różnej barwie miąższu. BROMAT. CHEM. TOKSYKOL. XLVIII, 3, 473-478

Piątkowska, E., Kopeć, A., Leszczyńska, T., (2011), Antocyjany - charakterystyka, występowanie i oddziaływanie na organizm człowieka. Żywność. Nauka. Technologia. Jakość. 4 (77), 24-35

Renis, M., Calandra, L., Scifo, C., Tomasello, B., Cardile, V., Vanella, L., Bei, R., Fauci, L. L., Galvano, F., (2007), Response of cell cycle/stress-related protein expression and DNA damage upon treatment of $\mathrm{CaCo} 2$ cells with anthocyanins. Br. J. Nutr., 100(1), $1-9$ 
Wierzbicka,A., Hallmann, E., Grudzińska, M.,(2015),Zawartość polifenoli w ziemniakach w zależności od odminay i efektywnych mikroorganizmów. Fragm. Agron. 32(4), 81-88

Zawistowski, J., Kopeć, A., Kitts, D. D., (2009), Effect of a Black rice extract (Oryza saliva L. indica) on cholesterol levels and plasma lipid parameters in Wistar Kyoto rats. J. Funct. Foods, 1, 50-56
Zhang, Y., Vareed, S. K., Nair, M. G., (2005), Human tumor cell growth inhibition by nontoxic anthocyanidins, the pigments in fruits and vegetables. Life Sci., 76, 1465-1472

Zimnoch-Guzowska, E., Flis, B., (2006), Genetyczne podstawy cech jakościowych ziemniaka. Zeszyty Problemowe Postępów Nauk Rolniczych, 511, 23-36

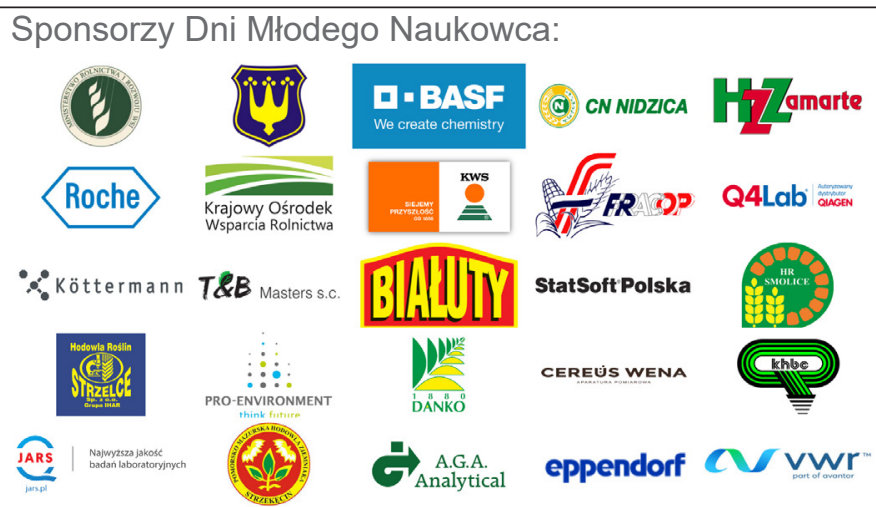

